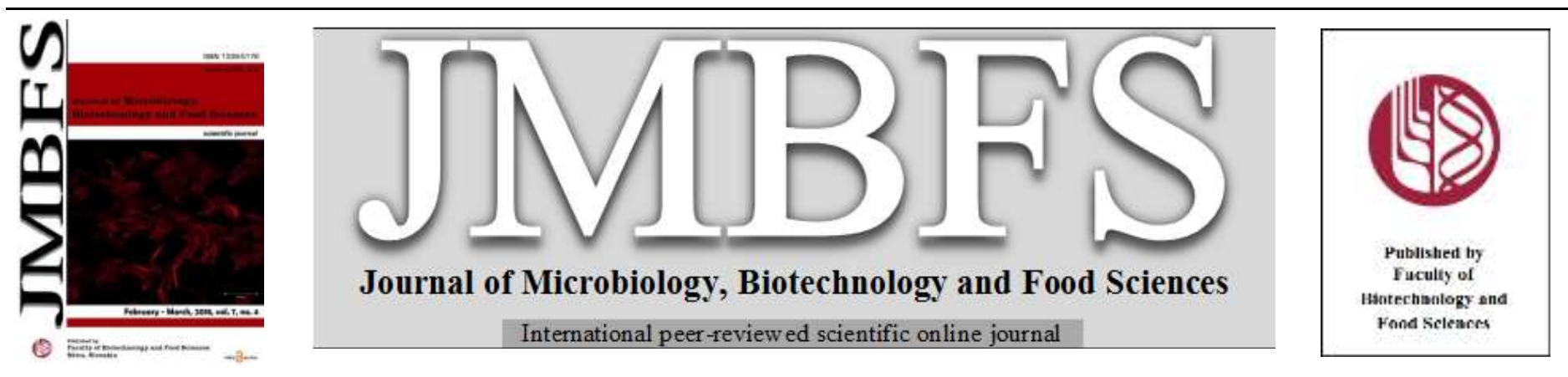

\title{
APPLICATION OF MICROBIAL FUEL CELLS FOR BIOREMEDIATION OF ENVIRONMENTAL POLLUTANTS: AN OVERVIEW
}

\author{
Sanjeeb Kumar Mandal ${ }^{1}$, Nilanjana Das $*^{l}$ \\ Address(es): Nilanjana Das, \\ ${ }^{1}$ Bioremediation Laboratory, School of Bio Sciences and Technology, Vellore Institute of Technology, Vellore-632014, India Tel: 91-416-2202478, Fax: 91-416- \\ 2243092.
}

*Corresponding author: nilanjana00@1ycos.com ; nilanjanamitra@ vit.ac.in

doi: 10.15414/jmbfs.2018.7.4.437-444

\section{ARTICLE INFO}

Received 23. 11. 2017

Revised 28. 12. 2017

Accepted 2. 1. 2018

Published 1. 2. 2018

Regular article

orten 2 actess

\begin{abstract}
Microbial fuel cells (MFCs) have been demonstrated as a challenging and promising technology towards management of various environmental problems. Bioremediation has been accepted widely as viable option utilizing the naturally inhabited microorganisms, but sometimes the severe low efficiency of the microorganisms and poor controllability limits its application. In this context, MFC technology can be used as a potential means to stimulate bioremediation for effective removal of various pollutants. The special features including energy saving, less sludge and energy production make MFCs as outstanding technology compared to conventional technologies. This article is mainly focused on application of MFCs towards removal of various environmental pollutants viz. antibiotics, synthetic dyes, phenolic compounds, nitrogen based compounds, ethyl acetate, toluene, polycyclic aromatic hydrocarbons, perchlorate, pesticide, sulphur, emerging contaminants, trace organic compounds etc. from aqueous environment. Although the current applications of MFC technology is still at laboratory level, it will definitely prove a great potential towards commercial applications in near future.
\end{abstract}

Keywords: Bioremediation, microbial fuel cell (MFC), pollutants, stimulation, wastewater

\section{INTRODUCTION}

Microbial fuel cells (MFCs) have gained enormous global importance over the last few decades. It is a device which uses bacteria for the oxidation of organic and inorganic substances in the anode for the bioremediation of pollutants along with the generation of bioelectricity (He et al., 2015). The major advantages of MFC technology towards remediation of pollutants include (i) less production of activated sludge (ii) gas treatment not necessary (iii) energy input not needed for aeration (iv) conversion of substrate energy to electricity directly and (v) can be operated at any temperature.

Wastewater containing various pollutants is the major causes for environmental pollution in surface and ground water bodies (Gude, 2016). Researchers across the globe have investigated the application of MFCs for the treatment of different types of wastewaters viz. municipal or domestic wastewater (Khan et al., 2017), food processing wastewater (Boghani et al., 2017), protein food industry wastewater (Ieropoulos $\boldsymbol{e t}$ al., 2017), acidogenic food waste leachate ( $\mathbf{L i}$ et al., 2013a), beverages industry wastewater (Çetinkaya et al., 2015), beer brewery wastewater (Köroglu et al., 2014), winery wastewater (Penteado et al., 2015), confectionary industry wastewater (Patil $\boldsymbol{e t}$ al., 2009), dairy industry wastewater (Mansoorian et al., 2016), yoghurt wastewater (Cercado-Quezada et al., 2010), agro-processing industry wastewater (Gurung and Oh, 2015), cassava mill wastewater (Sangeetha and Muthukumar, 2013), palm oil mill effluent (Nor et al., 2015), mustard tuber wastewater (Guo et al., 2015), livestock industry wastewater (Katuri et al., 2012), animal carcass wastewater (Li et al., 2013b), swine wastewater (Cheng et al., 2014), mining and allied industry wastewater (Choi and Hu, 2013), recalcitrant pharmaceutical industrial effluent (Zhang et al., 2015a), steroidal drug production wastewater (Liu et al., 2012), paper recycling industry wastewater (Kassongo and Togo, 2011) and petrochemical industry wastewater (Morris and Jin, 2012). The MFC technology has been accepted because of its eco-friendly approach compared to conventional technologies towards the control of environmental pollution.

Moreover, several reviewers have focused on various issues related to MFC technology including designs and configurations of MFCs, surface modifications of electrodes and electrode surface, power generation, analysis of microbia communities, operational conditions for performance and biofilm formation, various challenges and possibilities, fundamental electron transfer mechanisms, organic removal capacities, environmental impacts and economic answers towards industrial commercialization of MFCs etc. (He et al., 2015; Gude, 2016; Tharali et al., 2016). However, a comprehensive review on the application of MFCs towards remediation of pollutants is still lacking. Therefore, the present review aimed at summarizing the recent reports on application of MFCs towards removal of pollutants from aqueous environment.

\section{Microbial fuel cell}

Microbial fuel cell (MFC) unit is composed of an anode, cathode, cation sensitive membrane and an external wire. Aerobic and anaerobic conditions are maintained at the cathode and anode respectively. MFC can be operated with or without a mediator. Addition of external bacteria is needed for the oxidation of the substrate in case of mediated fuel cells (Saeed et al., 2015). The microorganisms in the anodic chamber are provided with a favourable substrate which are anaerobically degraded and release electrons. These electrons are transported from anode to the cathode through external circuit and the generated protons are passed selectively through membrane. In MFCs, chemical energy is being converted to electrical energy by oxidation of various carbon sources or organic wastes carried out by electrochemically active bacteria. There are different designs of MFCs depending upon the chambers viz. single chambered MFC, twochamber MFC, stacked MFC etc. (Tharali et al., 2016). Different types of MFCs viz. mediator-less MFC (Moon et al., 2006), membrane-less MFC, (Jadhav et al. 2013), catalyst coated electrode MFCs (Rahimnejad et al., 2015), sediment-type MFCs (Thomas et al., 2013) have also been reported. Proton exchange membranes (PEM) are important component of MFC which assist in separation of the anode and cathode chambers facilitating transfer of protons to cathode for sustaining the electric current (Chae et al., 2007).

\section{Environmental pollutants}

The application of MFCs for the remediation of various environmental pollutants viz. antibiotics, synthetic dyes, phenolic compounds, nitrogen based compounds, ethyl acetate, toluene, polycyclic aromatic hydrocarbons, perchlorate, pesticide, sulphur, emerging contaminants, trace organic compounds have been discussed below. 


\section{Antibiotics}

Antibiotics present in the aqueous environment have been considered as pollutants over the last few years (Popa et al., 2014). There is an urgent need for the removal of antibiotic compounds from wastewater releasing into the environment (Ahmed et al., 2015).

Chloramphenicol (CAP), a broad-spectrum nitroaromatic antibiotic has been extensively used in the animal breeding industry due to its cost effectiveness. But CAP has been banned for use in many developed countries due to its serious toxicity causing bone-marrow depression and aplastic anaemia in humans and animals (Martelli et al., 1991). Recently, Zhang et al. (2017a) studied the performance of a microbial fuel cell (MFC) for the degradation of chloramphenicol (CAP) which showed $84 \%$ degradation of $50 \mathrm{mg} \mathrm{l}^{-1}$ CAP within $12 \mathrm{~h}$ in the MFC

The rapid degradation of sulphamethoxazole (SMX), a broad-spectrum antibiotic has been reported using microbial fuel cell (MFC) (Wang et al., 2016). SMX and its degradation product, 3-amino-5-methylisoxazole (3A5MI) were found to be effectively degraded in MFC reactors. Degradation of SMX (20 ppm) was approximately $85 \%$ within $12 \mathrm{~h}$. The biodegradation rate was more rapid that has been reported so far in literature. The degradation product, (3A5MI), a toxic chemical which was formed in the SMX degradation process, could be further mineralized. Antibacterial activity test showed that the biotoxicity of SMX towards Shewanella oneidensis MR-1 and Escherichia coli DH5a was greatly reduced after MFC treatment. ATP level of the MFC microbe was almost three times higher than that in open-circuit controls which might be the reason for rapid degradation of SMX in MFCs.

Paracetamol (PAM) is a common analgesic and antipyretic drug which is generally safe for use at recommended dose. But small overdoses may lead to fatal liver damage (Yang $\boldsymbol{e t}$ al., 2009). PAM has emerged as an important wastewater contaminant due to its wide usage in pharmaceutical industries and daily life. The clinical trade name of PAM is acetaminophen (ACTP) or acetyl para-aminophenol (APAP). Zhang et al. (2015a) reported the bioelectrochemical degradation of paracetamol in a microbial fuel cell-Fenton system. Dual-chamber MFC reactors were used. For bio-electrochemica degradation of PAM, Fenton reactions were introduced to microbial fuel cells (MFCs) without external power supply. No continuous addition of Fenton reagents was required in MFC-Fenton system compared to conventional Fenton reactions system. Maximum PAM degradation efficiency of $70 \%$ was found within $9 \mathrm{hr}$ at initial $\mathrm{pH} 2.0$, external resistance $20 \mathrm{X}$ and total iron concentration of $5 \mathrm{mg} \mathrm{l}^{-1}$. PAM $(25 \%)$ could be completely mineralized and the majority was mainly converted to intermediate metabolites of p-nitrophenol via p-aminopheno and dicarboxylic/carboxylic acids which is less toxic. These results suggested that microbial fuel cell-Fenton system can be applied as an energy-saving and efficient tool for the remediation of PAM-containing wastewater.

\section{Phenolic compounds}

Phenols and phenolic compounds are being used in the petrochemical, oil refining, plastic and pharmaceutical industries. Exposure to phenol and its derivatives may lead to respiratory disorders, and long-term phenol inhalation may even lead to cancer (Calabrese and Kenyon, 1991). Disposal of these compounds to water bodies has become a great concern due to their toxicity and harmful effects to human and aquatic lives (Chen et al., 2013). The World Health Organization (WHO) indicated substituted phenols as most toxic substances for human health.

2,4-dichlorophenol (2,4-DCP) is the most recalcitrant and hazardous contaminan found in industrial wastewater. The maximum permissible limit for 2,4 dichlorophenol (2,4-DCP) is $40 \mu \mathrm{g}^{-1}$ (Davi and Gnadi 1999). Hassan et al. (2016a) used pure culture $B$. subtilis for degradation of recalcitrant toxic compounds through MFC systems. Hassan et al. (2016b) explored the degradation of 2,4-DCP in a double chamber microbial fuel cell (MFC) using the bacteria Bacillus subtilis. MFC system enabled the removal of contaminants by the bacteria with concurrent electricity generation through electron transfer mechanisms. The exoelectrogenic bacterium B. subtilis was found to show good capability for generating maximal power density of $9.5 \mathrm{~mW} \mathrm{~m}^{-2}$ with a peak current $1.11 \mathrm{~mA}$ over a potential $0.45 \mathrm{~V}$, while degrading over $60 \% 2,4$ dichlorophenol. The change of $\mathrm{pH}$ and chemical properties of potassium persulfate as catholytes showed significant impact on bio-electrochemical activities. Based on the results, the B. subtilis-catalysed MFC was reported as feasible technology for remediation of toxic phenol pollutants from industrial wastewater.

Hedbavna et al. (2016) reported the biodegradation of phenolic compounds and their metabolites in contaminated groundwater using microbial fuel cells. This was the first report on application of bioelectrochemical systems (BESs) on biodegradation of phenolic compounds and their organic metabolites in contaminated groundwater. The anaerobic biodegradation of phenol occurred via 4-hydroxybenzoic acid and 4-hydroxy-3-methylbenzoic acid in the anode chamber. The electrode along with sulphate, nitrate, oxygen, iron (III) were electron acceptors for biodegradation. The electricity $\left(\sim 1.8 \mathrm{~mW} \mathrm{m^{-2 }}\right)$ was produced by electro-active bacteria attached to the anode, while acetate was utilized as an electron donor. Removal of acetate was enhanced by $40 \%$ in the presence of the anode. However, enhanced removal of phenols occurred only for a short time.

A microbial fuel cell (MFC), with graphite electrodes as both the anode and cathode, was reported by Zhang et al. (2017b) for phenol degradation. It was operated with a soil-free anaerobic consortium. High efficiency with a curren density of $120 \mathrm{~mA} \mathrm{~m}^{-2}$ and a coulombic efficiency of $22.7 \%$ were shown by this phenol-degrading MFC. The phenol-degrading MFC was maintained by the microorganisms in the anode biofilm, not by the planktonic bacteria. The structure of microbial community of the anode biofilm and the planktonic bacteria was analysed based on 16S rRNA gene sequences. Geobacter sp. was suggested the phenol degrader in the anode biofilm which was responsible for current generation.

Application of dual chamber microbial fuel cell (MFC) operated at fed batch mode was reported for the treatment of coconut husk retting wastewater containing phenol at a concentration of $320 \pm 60 \mathrm{~g} \mathrm{~m}^{-3}$ (Jayashree et al., 2014) Hydraulic retention time (HRT) of the reactor was varied from 40 days to 10 days. Highest phenol removal of $93 \%$ at 40 days HRT of the microbial fuel cell was noted. The bacterial strains viz. Ochrobactrum sp. RA1 (KJ408266), Ochrobactrum sp. RA2 (KJ408267) and Pseudomonas aeruginosa RA3 (KJ408268 in anode region were reported to be responsible for potential phenol removal.

Efficient strategies for faster start up and quick pentachlorophenol (PCP) degradation were explored using of MFC (Huang et al., 2013a). There were reports on degradation of recalcitrant (PCP) in both the bioanodes and the biocathodes of MFCs (Huang et al., 2012) but the start up time was very long and PCP degradation was very slow. In bioelectrochemical cells (BECs), development of biocathodes at $-300 \mathrm{mV}$ vs. SHE (versus standard hydrogen electrode) and bioanodes formed at an optimal potential of $200 \mathrm{mV}$ vs. SHE enhanced the performances of MFCs compared to the un-treated controls. PCP degradation rates were improved by $21.5 \%$ in biocathodes and $28.5 \%$ in bioanodes. The start-up times were reduced to $320 \mathrm{~h}$ in bioanodes and $420-440 \mathrm{~h}$ in biocathodes. The bacteria viz. Desulfovibrio marrakechensis, Comamonas testosteroni and Comamonas sp. on the biocathodes at $-300 \mathrm{mV}$ and Desulfovibrio carbinoliphilus and Dechlorospirillum sp. on the bioanodes at 200 $\mathrm{mV}$ were included as recalcitrant organic degraders and/or exoelectrogens/electrotrophs. This was found to be a feasible approach to develop both bioanodes and biocathodes for efficient PCP degradation.

Mineralization of 4-chlorophenol (4-CP) in microbial fuel cells was reported by Huang et al. (2013b). The 4-CP is found in industrial wastewaters, soils, surface waters and ground water (Field and Sierra-Alvarez, 2008). It was cometabolically degraded and mineralized in presence of glucose in microbial fue cells (MFCs). The degradation rate was $0.58 \pm 0.036 \mathrm{mg} \mathrm{l}^{-1} \mathrm{~h}^{-1}\left(7.2 \pm 0.5 \mathrm{mg} \mathrm{g}^{-1}\right.$ VSS-h).

p-Nitrophenol (PNP) is an important nitro-aromatic compound which is used in manufacturing of dyes, explosives, fungicides, industrial solvent and organic phosphorus pesticide (Kuosa and Kallas, 2009). PNP is recognized as list I toxic pollutant by the European Economic Community and a priority pollutant by the US Environmental Protection Agency. The permissible limit of PNP in natura water is restricted to less than $10 \mathrm{mg} \mathrm{l}^{-1}$ for environmental safety (Zhang $\boldsymbol{e t}$ al. 2009). Degradation of p-nitrophenol (PNP) was monitored in a two-chambered microbial fuel cell (MFC) system (Liu et al., 2013). The results showed that maximum PNP degradation was $64.69 \%$ when PNP was used as a sole substrate. Electrosorption driven microbial fuel cells was used for the removal of phenol without external power supply (Yang et al., 2013). During MFC sorption, the operating parameters viz. $\mathrm{pH}$, electrolyte concentration, initial phenol concentration, MFCs connection numbers and mode were studied along with adsorption isotherms and kinetics of a novel electrosorption driven by microbial fuel cells. Maximum adsorption capacity by MFC-sorption and electrosorption was observed $48 \%$ and $65 \%$ higher than that by conventional adsorption. The initial adsorption rate of phenol was increased 26.99-fold with an increase of initial phenol concentration from $20 \mathrm{mg} \mathrm{l}^{-1}$ to $300 \mathrm{mg} \mathrm{l}^{-1}$.

\section{Synthetic dyes}

Synthetic dyes released from printing, textile, leather and other industries are considered as recalcitrant pollutants containing complex structure which cannot be degraded easily (Devi $\boldsymbol{e t}$ al., 2009). Azo dye is very widely used in dye industry but it has been found to be highly toxic and mutagenic (Bafana et al. 2011). MFC has shown the ability to decolorize azo dye, a widespread environmental pollutant associated with dye manufacturing industry, while simultaneously generating bioelectricity (Sun et al., 2011).

Recently, application of microbial fuel cell (MFC) with redox mediator modified anode was reported for enhancing simultaneous decolorization of azo dye and electricity generation (Huang et al., 2017). Redox mediator (RM) modified anodes were made by electrodepositing riboflavin (RF) and humic acid (HA) on the surface of graphite felt. Air-cathode single-chamber MFCs with different modified anodes were built for decolorization of Congo red and generation of bioelectricity. Compared to the bare anode MFC, MFC with 0.5C RF, 0.5C HA 1.25C RF and 2.5C HA modified anode exhibited excellent electrocatalysis 
activity. MFCs with $2.5 \mathrm{C}$ HA and $1.25 \mathrm{C}$ RF modified anode showed high decolorization efficiency of Congo red to $86 \%$ and $75 \%$ in $16 \mathrm{~h}$. Significant RM crystals on the modified anodes, and bacterial colonies on the anode surface were noted after MFC running. The RM crystals on the modified anodes could accelerate electron transfer for decolorization and bioelectricity generation both. Novel bioelectro-Fenton technology was applied for azo dye wastewater treatment using microbial reverse-electrodialysis electrolysis cell (Hou et al., 2017). The single-chamber microbial electrolysis cell was constructed with a $\mathrm{TiO}_{2}$-coated photocathode termed as photocatalytic microbial electrolysis cel (PMEC). The PMEC was developed to accelerate methyl orange (MO) degradation and concurrent hydrogen $\left(\mathrm{H}_{2}\right)$ recovery under UV irradiation. Faster MO decolorization rates were achieved from the PMEC compared with those without UV irradiation or with open circuit. With increase of MO concentration ranging from 50 to $300 \mathrm{mg} \mathrm{l}^{-1}$ at an applied voltage of $0.8 \mathrm{~V}$, decolorization efficiencies was found to decrease from $98 \%$ to $76 \%$ within $12 \mathrm{~h}$, and cyclic $\mathrm{H}_{2}$ production was reduced from 113 to $68 \mathrm{ml}$. Bioelectrochemical reduction, cometabolism reduction and photocatalysis were involved as the possible mechanism of MO degradation. The intermediates of MO mainly sulfanilic acid and $\mathrm{N}, \mathrm{N}$-dimethylaniline were further degraded by $\mathrm{OH}$ generated from photocatalysis. This could make MO mineralization possible in the singlechamber PMEC.

An innovative concept of using microbial reverse-electrodialysis electrolysis cell (MREC) based Fenton process was proposed for the treatment of azo dye Orange $\mathrm{G}$ bearing wastewater (Li et al., 2017). In this integrated process, the production of $\mathrm{H}_{2} \mathrm{O}_{2}$ was key reactant of Fenton-reaction driven by the electrons harvested from the exoelectrogens and salinity-gradient between sea water and fresh water in MREC. Complete decolorization and mineralization of Orange $G$ at concentration of $400 \mathrm{mg} \mathrm{l}^{-1}$ was achieved.

Oon et al. (2017) reported the application of microbial fuel cell (MFC) using monoazo and diazo dyes as terminal electron acceptor for simultaneous decolourisation and bioelectricity generation. Monoazo and diazo dyes [N Acid orange 7 (AO7), New coccine (NC), Reactive green 19 (RG19) and Reactive red 120 (RR120)] were chosen as electron acceptors in the abiotic cathode of MFC. When NC was employed as the electron acceptor, the chemical oxygen demand (COD) removal and dye decolourisation efficiencies obtained at the anodic and cathodic chamber were $73 \pm 3 \%$ and $95.1 \pm 1.1 \%$, respectively. The results showed that the rates of decolourisation of monoazo dyes were $\sim 50 \%$ higher than diazodyes.

A stacked microbial fuel cell-biofilm electrode reactor (BER) coupled system was applied for the enhanced degradation of azo dye, Reactive Brilliant Red X3B (Cao et al., 2017). Electrical energy generated by the MFC degraded the azo dye in the BER in this system without the need for an external power supply. The effluent from the BER was used as the inflow for the MFC with furthe degradation. The results showed that removal of X-3B was $29.87 \%$ higher using this coupled system than in a control group.

Sun et al. (2016) reported the performance of biocathode microbial fuel cell with respect to azo dye degradation using two anodic inoculums, textile dyeing sludge (MFC-I) and municipal sludge (MFC-M). The results showed that the MFC-I exhibited excellent performance in Congo red decolorization, whereas the MFC$\mathrm{M}$ performed well in electricity generation. The MFC-I achieved fast Congo red decolorization. The MFC-M exhibited 3.22 times higher power output $(29 \mathrm{~mW}$ $\mathrm{m}^{-2}$ vs. $9 \mathrm{~mW} \mathrm{~m}^{-2}$ ) and $38.0 \%$ lower anode impedance (749 U vs. $1208 \mathrm{U}$ ) compared to MFC-I. The stains isolated from anodic biofilm of MFC-I were identified as Pseudomonas sp. and Aquamicrobium sp. whereas the isolates from MFC-M belonged to Pseudomonas sp. and Bacillus sp. These four selected isolates were proved to be exoelectrogens and simultaneous decolorizer which exhibited different dye decolorizing potentialities and bioelectrocatalytic activities.

Microbial fuel cell coupled constructed wetland (CW-MFC) was used for azo dye Methyl Orange (MO) decolorization and further degradation (Fang et al., 2016) The N, N-Dimethyl-p-phenylenediamine (DMPD), 1,4-Benzenediamine, Nmethyl- and p-Phenylenediamine (PPD) were intermediate products formed during MO decolorization. The decolorization rate of $\mathrm{MO}$ in closed and opencircuit CW-MFC were and $87.60 \%$ and $75.59 \%$ respectively. The degradation rate of DMPD in the anode layer of closed and open-circuit CW-MFC were 96.33 $\%$ and $84.96 \%$ respectively. In the anode layer, further degradation of azo dye degradation products was possible using suitable anode materials. But in the cathode layer, close current promoted further degradation of the decolorization products.

Nordin et al. (2017) developed a novel hybrid system composed of a photocatalytic fuel cell (PFC) and Fenton reactor for degradation of azo dye Reactive Black 5(RB5) and generate electricity. Compared to previously reported bioelectro-Fenton system, microbial fuel cell (MFC) system has significant challenge towards the development and operation system. Instead of MFC, PFC was used to generate electrons for the Fenton system. In the PFC reactor hybrid system, higher degradation efficiency of RB5 was observed.

The first-attempt was made by Hong $\boldsymbol{e t}$ al. (2016) on optimal operation mode(s) of microbial fuel cells (MFCs)-assisted decontamination of azo dye, Reactive Blue 160. Internal resistances could be significantly reduced for effective electron transfer (ET) to dye decolorization (DD) and bioelectricity generation
(BG) with supplementation of energy substrate(s) and textile dye(s). The results showed that increase in nutrient substrates and azo dye- reactive blue 160 favoured dye decolourization (DD) in MFC systems.

A highly efficient single chambered up-flow membrane-less microbial fuel cell was used for the treatment of azo dye Acid Orange 7-containing wastewater (Thung et al., 2015). Single chambered up-flow membrane-less microbial fuel cell (UFML MFC) was developed to study the decolorization of Acid Orange 7(AO7) and electricity generation simultaneously. The performance of UFML MFC was evaluated in terms of voltage output, chemical oxygen demand (COD) and color removal efficiency by varying the concentration of AO7 in synthetic wastewater. The results showed the voltage generation and COD removal efficiency decreased along with the increase of initial $\mathrm{AO} 7$ concentration which indicated that there was electron competition between anode and azo dye. The breakdown of the azo bond and naphthalene compound in $\mathrm{AO} 7$ were confirmed based on UV-visible spectra analysis.

A single-chamber microbial fuel cell (MFC) with an aeration electrochemical system was proposed for decolorization of a typical azo dye, Methyl orange (MO) which is a well-known recalcitrant pollutant in dye wastewater (Zhang $\boldsymbol{e t}$ al., 2015b). The color removal observed was $90.4 \%$ within $360 \mathrm{~min}$ with voltage across the aeration electrolytic reactor fixed at $700 \mathrm{mV}$. The GC-MS analysis indicated the degradation of MO, with generation of benzene derivatives, low molecular weight compounds. The indirect electrochemical oxidation of MO by generated $\mathrm{H}_{2} \mathrm{O}_{2}$ was mainly responsible for $\mathrm{MO}$ decolorization.

Hsueh et al. (2014) reported the reductive biodegradation of reactive green 19 (RG19) in Enterobacter cancerogenus BYm30 in single chamber membrane-less microbial fuel cell (SCML-MFC) and non-MFC cultures. The results indicated that menaquinone from BYm30 might have played a role as an electron-shuttling carrier or a redox mediator for stimulation of dye decolorization and bioelectricity generation in MFC. Color removal in MFC was significantly faster than non-MFC cultures due to the formation of reduced organic sulfides from RG19 in MFC. Moreover, tertiary alcohols and phenols which were present in LB broth might have degraded by BYm30 under anaerobic condition irrespective of MFC or non-MFC condition.

Kalleary et al. (2014) highlighted the application potential of microbia desalination Cell (MDC) for effective biodecolourisation of industrial dyes. This was the first report where dye house effluent was used as an organic substrate in MDC and biodecolourisation of effluent along with considerable desalination and power production was achieved. Two novel bacterial strains, viz. Bacillus subtilis moh3 and a MTCC strain Aeromonas hydrophila subsp. hydrophila 8049 were used for decolourisation of two model dyes-Malachite Green (C.I.42,000) and Sunset Yellow (C.I.15,985). Complete biodecolourisation along with considerable desalination $(62.2 \pm 0.4 \%$ and $57.6 \pm 0.2 \%)$ and power production were seen using these novel cultures.

Bacterial-fungal interactions can enhance the power generation in microbial fuel cells and drive dye decolourisation of dyes (de Dios et al., 2013). The potential for sustainable energy production from wastes was tested using a combination fungus-bacterium in microbial fuel cell (MFC) and electro-Fenton technology. The fungus Trametes versicolor was grown with Shewanella oneidensis so that the bacterium could use the networks of the fungus for the transport of electrons to the anode. Stable electricity was generated with stable voltage of $1000 \mathrm{mV}$ approximately. Due to the dual benefits of the in situ-designed MFC electroFenton, the simultaneous dye decolourisation and the electricity generation were demonstrated. This newly developed MFC fungus-bacterium with an in situ electro-Fenton system could ensure a high-power output and a continuous degradation of organic pollutants.

A microbial fuel cell coupled constructed wetland (CW) (planted with Ipomoea aquatica) system was used for azo dye decolorization (Fang et al., 2013) Electricity was simultaneously produced during the co-metabolism process of glucose and azo dye. The results showed that plants grown in cathode could enhance the cathode potential and promoted dye decolorization. The electrodes promoted the dye decolorization efficiency in the anode. The planted CW-MFC system achieved highest decolorization rate of $91.24 \%$ and a voltage output of $610 \mathrm{mV}$.

Enhanced simultaneous decolorization of Congo red and bioelectricity generation with anthraquinone-2,6-disulphonic disodium salt (AQDS), riboflavin (RF) and humic acid (HA) as mediators in air-cathode microbial fuel cell (MFC) was demonstrated (Sun et al., 2013). The MFC with added $0.005 \mathrm{mmol}^{-1}$ AQDS, $0.005 \mathrm{~m} \mathrm{~mol} \mathrm{l}^{-1} \mathrm{RF}$ or $1 \mathrm{~g} \mathrm{l}^{-1} \mathrm{HA}$ showed $36 \%, 26 \%$ and $15 \%$ increase in maximum power density along with $394 \%, 450 \%$, and $258 \%$ increases in decolorization rates of Congo red, respectively compared with mediator-free MFC. At higher concentration, addition of mediators further increased power and Congo red decolorization. Microbial analysis showed that addition of mediators changed the composition of anodic microbial community and stimulated the growth of species belonging to Chlorobi, Endomicrobia and Firmicutes.

Xu et al. (2013) investigated the functions and interactions of predominant microorganisms in microbial fuel cells (MFCs) for simultaneous electricity generation and Congo red decolorization. Four strains isolated from the anodic biofilm, and identified as Pseudomonas (M-P and I-P), Bacillus (M-B) and Aquamicrobium (I-A). Using pure cultures, I-P and M-P as inoculums, lower Congo red decolorization rate (by $3.2 \%$ and $5.9 \%$ ) and higher maximum power 
density (by $158.2 \%$ and $58.1 \%$ ) were achieved in MFCs than those using I-A and $\mathrm{M}-\mathrm{B}$, respectively. Using co-cultures (MP and $\mathrm{B}$ versus $\mathrm{M}-\mathrm{B}$ and $\mathrm{M}-\mathrm{P}, \mathrm{I}-$ $\mathrm{P} \& \mathrm{~A}$ versus I-A and I-P), the maximum power density of MFCs were increased $82.0 \%, 15.1 \%, 94.6 \%$ and $24.6 \%$ but decolorization rate decreased $33.3 \%$, $29.4 \%, 7.9 \%$ and $5.0 \%$ respectively. The results indicated that specific interaction could enhance the performance of MFCs and which may be beneficial for the development of bio-process controlling.

\section{Nitrogen based compounds}

Among various global environmental pollutions, nitrogen-containing organic compounds have drawn extensive attention as recalcitrant pollutants in the last few decades. They usually contain compounds like aromatic rings or azo bond having complex structure that may cause harmful and irreversible environmenta problems even at quite low concentrations (Devi et al., 2009).

Wang et al. (2015a) proposed a promising single-chamber microbial fuel cells (MFCs) as renewable power sources, an aerated electrochemical system for removal of nitrogen-containing organic compounds (pyridine and methyl orange). Lower initial contaminant concentration and lower initial $\mathrm{pH}$ value could improve the performance of MFC. A degradation efficiency of $82.9 \%$ for pyridine was achieved after $360 \mathrm{~min}$ electrolysis at initial $\mathrm{pH} 3.0$, initia concentration $200 \mathrm{mg} \mathrm{l}^{-1}$, and applied voltage $700 \mathrm{mV}$. Indirect electrochemica oxidation by generated hydrogen peroxide was responsible for their degradation. Nitrogen removal in continuous flow microbial fuel cell (MFC) and microbial electrolysis cell (MEC) was reported under laboratory condition (Hussain $\boldsymbol{e t}$ al. 2016). An ammonium removal efficiency of 30-55\% with near-zero nitrite and nitrate concentrations was observed in the MFC operated at an optimal external resistance. An open-circuit MFC operation resulted reduced ammonium removal of $21 \%$. In the MEC, removal of ammonium was limited to 7-12\% under anaerobic conditions. Removal efficiency was increased to $31 \%$ under microaerobic conditions. Ammonium removal efficiency was reduced to $4 \%$ at zero applied voltage.

During last few decades, nitrate pollution in groundwater has become a serious issue in most parts of the world due to discharge of domestic, industria wastewater and increased usage of nitrogenous fertilizers (Park et al., 2005). Excessive nitrate can do harm to humans and animals. causing methemoglobinemia or blue baby syndrome in infants and gastrointestinal cancer in adults (Mousavi et al., 2012). Thus, the maximum contaminant levels (MCL) are stipulated to be $10 \mathrm{mg} \mathrm{l}^{-1}$ nitrate nitrogen $\left(\mathrm{NO}_{3}^{-}-\mathrm{N}\right)$ and $1 \mathrm{mg} \mathrm{l}^{-1}$ nitrite nitrogen $\left(\mathrm{NO}_{2}^{-}-\mathrm{N}\right)$ respectively by both USEPA and China.

Zhang et al. (2014) demonstrated the enhancement of bacterial denitrification for nitrate removal in groundwater with electrical stimulation from microbial fue cells. Electricity generated from the microbial fuel cell (MFC) was applied to the bioelectrical reactor (BER) directly as electrical stimulation means for the enhancement of bacterial denitrification to remove nitrate effectively from groundwater. With maximum power density of $502.5 \mathrm{~mW} \mathrm{~m}^{-2}$ and voltage outputs ranging from $500 \mathrm{mV}$ to $700 \mathrm{mV}$, the nitrate removal was accelerated with less intermediates accumulation, compared with control sets without electrical stimulation. Denitrification bacteria proliferations and activities were promoted as its number and Adenosine-5'-triphosphate (ATP) concentration increased 1.5 folds in one order of magnitude $\left(3.5 \times 10^{7}\right.$ in per millilitre biofilm solution). Effects of electricity from MFCs on enhancement of bacterial behaviours were reported for the first time.

\section{Ethyl Acetate (EA)}

Ethyl acetate (EA), a VOC, is an organic solvent which is highly volatile and damaging to the respiratory system (Coopman et al., 2005). It is commonly used as a solvent in varnish, adhesives, paint, and organic syntheses, especially food and pharmaceutical industries (Kleinbeck et al., 2008). Exhaust emissions of VOCs from various industrial sources cause environmental damage and human health hazard (Mohseni and Allen, 2000). Prolonged exposure to EA irritates human eyes. High concentration of EA steam may cause health hazards such as headache and fatigue (Wu and Lin, 2016).

Wu et al. (2016a) developed an innovative biotrickling filter-microbial fuel cell (BF-MFC) for the use in electricity production and removal of ethyl acetate (EA) emitted from a gaseous stream. A new membrane design was developed which provided effective delivery of protons released from microorganisms biodegrading EA from the anode to the cathode using a polyvinyl alcoholmembrane electrode assembly. The elimination capacity (EC) reached almost the $100 \%$ as the EA concentration was increased from $0.18 \mathrm{~g} \mathrm{~m}^{-3}$ to $1.44 \mathrm{~g} \mathrm{~m}^{-3}$ along with the increase of the voltage increased from $49.4 \mathrm{mV}$ to $658 \mathrm{mV}$, and EA organic loading rate ranged from 14.41 to $29.58 \mathrm{~g} \mathrm{~m}^{-3} \mathrm{~h}^{-1}$. Microbia community analysis revealed that two distinct groups of exoelectrogenic microbes and EA-degraders were mainly involved in the conductive coke surface and in the inner tube wall of the BF-MFC, respectively.

The modification of membrane anode was done in the microbial fuel cell to improve the removal of gaseous ethyl acetate without reducing generation of electricity (Wu et al., 2016b). An S-type flow-field pipe-microbial fuel cell
(SFP-MFC) was developed to remove ethyl acetate (EA) from an air stream. The SFP-MFC included the use of polyvinyl alcohol and a membrane electrode assembly (PVA-MEA) as the gas diffusion membrane and proton exchange membrane (PEM) which could separate anode from the cathode. The performance of the SFP-MFC system was evaluated with an empty bed residence time (EBRT) of $14.35 \mathrm{~s}$ and an organic loading rate of $63-3700 \mathrm{~g} \mathrm{~m}^{-3} \mathrm{~h}^{-1}$, with or without the modification of the PVA-MEA electrode using conductive carbon black (CCB). The maximum elimination capacity (EC) and voltage were $2288 \mathrm{~g}$ $\mathrm{m}^{-3} \mathrm{~h}^{-1}$ and $330 \mathrm{mV}$, respectively, which were obtained when the PVA-MEA was modified using CCB. The PVA-MEA that was modified with CCB which exhibited a $90 \%$ higher EA elimination capacity than the PVA-MEA without CCB modification. The maximum EC and EBRT of the modified SFP-MFC were 3-10 times higher and 2-12 times shorter, respectively, than those of biotrickling filter.

\section{Toluene}

Toluene is a common solvent and used as a raw material for the production of xylene and benzene. Global consumption of toluene has now reached $2 \times 10^{7}$ tons annually (Morata et al., 1995). Toluene is a toxic, refractory and mutagenic pollutant (Asenjo et al., 2011).

Wu et al. (2014) tested the toluene degradation and electricity generation under varying toluene doses. Pyocyanin was added to evaluate the effectiveness in improving electricity generation via toluene degradation. Addition of pyocyanin significantly improved electricity generation by reducing system impedance, increasing electron density and substantially lowering the internal resistance of microbial fuel cell (from 500 to $100 \mathrm{~V}$ ). The results of this study demonstrated the possibility of adding pyocyanin for enhanced power generation in a toluenefed MFC which can be used for the treatment of xenobiotics-contaminated wastewater like toluene.

A new anode design allowing direct delivery of the gaseous substrate to the biofilm was developed by spraying an additional hydrophobic gas layer and PTFE layers onto the gas side of the anode (Li et al., 2013c). The MFC with this design exhibited a two-fold increase in the toluene removal efficiency (from 43.1 \pm 2.7 to $91.2 \pm 2.4 \%$ ) and an approximately eight-fold increase in the maximum power density (from $0.72 \pm 0.02$ to $6.19 \pm 0.45 \mathrm{~mW} \mathrm{~m}^{-2}$ ) compared to the MFC equipped with a sparger for toluene delivery. MFC also showed a maximum toluene elimination capacity of $274.5 \pm 14.4 \mathrm{~g} \mathrm{~m}^{-3} \mathrm{~h}^{-1}$, which was higher than the values usually reported for biofiltration systems and biotrickling filters.

\section{Polycyclic aromatic hydrocarbons (PAHs)}

Pollution of groundwater by polycyclic aromatic hydrocarbons (PAHs) is a serious threat to human health as the hydrocarbons are toxic, mutagenic and carcinogenic. MFCs could be employed in the treatment of these recalcitrant pollutants with concomitant bioelectricity generation (Morris and Jin, 2012). The treatment of a mixture of phenanthrene and benzene using two different tubular microbial fuel cells (MFCs) were designed for either in situ and ex situ applications in aqueous systems over long periods (up to 155 days) (Adelaja $\boldsymbol{e}$ al., 2017). Simultaneous removal of the petroleum hydrocarbons ( $>90 \%$ in term of degradation efficiency) and bromate, used as catholyte (up to $79 \%$ ) with concomitant biogenic electricity generation (peak power density up to $6.75 \mathrm{~mW}$ $\mathrm{m}^{-2}$ ) were obtained at a hydraulic retention time (HRT) of 10 days for in situ studies. In the MFC designed for ex situ studies, optimum MFC performance was obtained at HRT of $30 \mathrm{~h}$ showing COD removal and maximum power output of approximately $77 \%$ and $6.75 \mathrm{~mW} \mathrm{~m}^{-2}$ respectively. The results of this study suggested the potential use of MFC technology for in situ/ex situ petroleum hydrocarbon-contaminated groundwater treatment even at extreme toxic level conditions.

A sediment microbial fuel cell (SMFC) was explored to bioremediate polycyclic aromatic hydrocarbons (PAHs) in water originated from soil. Sherafatmand and Ng (2015) reported the ability of SMFCs in stimulating microorganisms for bioremediation of complex and recalcitrant PAHs. The results showed consistent power generations of $6.02 \pm 0.34$ and $3.63 \pm 0.37 \mathrm{~mW} \mathrm{~m}^{-2}$ under an external resistance of $1500 \Omega$ by the aerobic and anaerobic SMFC respectively. Although the power generations were low, the significant benefit of this system was its bioremediation capabilities, achieving removal of naphthalene (41.7\%), acenaphthene $(31.4 \%)$ and phenanthrene $(36.2 \%)$ respectively in the aerobic environment and respectively, In the anaerobic environment, the removal was $76.9 \%$ for naphthalene, $52.5 \%$ for acenaphthene and $36.8 \%$ for phenanthrene was noted.

The use of MFCs in biodegradation of phenanthrene was investigated with respect to its biodegradation rate, biodegradation efficiency and power production using different inocula (Shewanella oneidensis MR1 14063 , Pseudomonas aeruginosa NCTC 10662, mixed cultures, and combinations) (Adelaja et al., 2014). All the inocula showed high capacity for phenanthrene degradation with a minimum degradation efficiency of $97 \%$. The best overall performing inoculum was anaerobically digested sludge supplemented with $P$. aeruginosa NCTC 10662, having a degradation rate, maximum power density 
and COD removal efficiency of $27.30 \mu \mathrm{mol} \mathrm{l}^{-1} \mathrm{~d}^{-1}, 1.25 \mathrm{~mW} \mathrm{~m}^{-2}$ and $65.6 \%$, respectively.

\section{Pesticide}

Hexachlorobenzene (HCB), as refractory organic pesticide, is toxic to human beings and environment. A range of remedial techniques were developed to remove toxic refractory organics in soil. The soil microbial fuel cells (MFCs) were constructed in the topsoil contaminated with toxic refractory organic pesticide, hexachlorobenzene (HCB). The performance of electricity generation and HCB degradation in the soil-MFCs were investigated (Cao et al., 2015). The HCB removal efficiencies in the three groups viz. (i) soil MFCs group (ii) open circuit control group and (iii) no adding anaerobic sludge blank group were 71.15 $\%, 52.49 \%$ and $38.92 \%$, respectively. The highest detected power density was $77.5 \mathrm{~mW} \mathrm{~m}^{-2}$ at the external resistance of $1000 \Omega$. HCB was degraded via the reductive dechlorination pathway in the soil MFC under anaerobic condition. The existence of the anode promoted electrogenic bacteria provided more electrons which could promote the removal efficiencies of HCB in soil MFC.

\section{Perchlorate}

Perchlorate $\left(\mathrm{ClO}^{-}\right)$is a major inorganic pollutant which is widely used in the manufacture of automobile airbags, missiles, road flares, rocket propellants, fireworks etc. and ultimately enters water resources (Xu et al., 2015). Presence of perchlorate has been observed in bottled water, groundwater, vegetables, rice, milk. It shows direct effect on the uptake of iodine by the thyroid gland (Wang $\boldsymbol{e} t$ al., 2014). So, the removal of perchlorate from wastewater has become an important environmental issue now days. There are few studies on the use of MFCs to treat perchlorate.

Lian et al. (2016) reported that resazurin as mediator could improve the performance of microbial fuel cells (MFCs) for the removal of perchlorate. MFCs with $3 \mu \mathrm{mol} \mathrm{l}^{-1}$ resazurin, $6 \mu \mathrm{mol} \mathrm{l}^{-1}$ resazurin, and $9 \mu \mathrm{mol} \mathrm{l}^{-1}$ resazurin showed increases in perchlorate reduction ratio of $50.8 \%, 72.6 \%$ and $101.6 \%$, respectively, compared with a mediator-free MFC. Increases in the output voltage of $24.5 \%, 33.3 \%$ and $41.7 \%$, respectively was also noted. Addition of resazurin decreased the anode resistance and enhanced the biocatalytic activities of the anode. Addition of resazurin changed the composition of the anodic microbial community which stimulated the growth of certain dominant microbes for the removal of perchlorate.

The effects of different electron donors and electron acceptors on the performance of microbial fuel cell (MFC) for perchlorate removal were investigated (Lian et al., 2017). The results of microbial analysis showed that the electron acceptors did not change the composition of the anodic microbial community. Dominant species were responsible for the enhancement of the higher perchlorate reduction rate and the higher output voltage.

\section{Sulfur}

Sulfur species at high concentration are harmful to living organisms. These sulfur pollutants are present in many processes such as pulp and leather, animal husbandry, detergent manufacture, mining, dye and food processing (Lens and Pol, 2000). Most of dissolved sulfur species flow into sea with the surface runoff. Sulfur pollutants negatively affect the natural ecosystems. Microbial fuel cells (MFCs) have been used as a promising technique for the removal of sulfur pollutants in wastewater. Fang-Yuan et al. (2013) described the roles of electrode chemical reaction and involvement of microorganisms in sulfur pollutants treatment using MFCs. The effecting factors and mechanism of treatment were demonstrated. The separator types, electrode materials and catalysts, sulfur recovery and electrode regeneration were also demonstrated. In addition, the feasibility of sulfur pollutants removal in MFCs was assessed by capital cost assessment.

\section{Emerging contaminants (ECs)}

The discharge of emerging contaminants (ECs) into the aquatic environment has become a great concern now-a-days due to their negative effects on the ecosystem. A number of endocrine disruptors and antibiotic resistant microorganisms were observed due to long-term contact of EC (Sun et al., 2012) Wastewater treatment plants (WWTPs) are the primary sources for the release of ECs into the water environment (Yu and Chu, 2009).

Wang et al. (2017) investigated the removal of four ECs viz. Bisphenol A (BPA), Estrone (E1), Sulfamethazine (SM2), Triclocarban (TCC) using the microbial fuel cell (MFC)-Fenton system. Glucose and graphite rod with stacked graphite granules were used as the substrate and electrode, respectively. Both batch and continuous flow modes of MFCs were compared. Successful application of the MFC-Fenton technology for the effective removal of ECs viz. E1, BPA, TCC and SM2 was demonstrated which may provide a cost-effective and promising alternative strategy for ECs removal in future.

\section{Trace organic compounds (TOrCs)}

Trace organic compounds (TOrCs) are reported as common contaminants in domestic wastewater resulting from human activities like disinfection by products, personal care products, pesticides and pharmaceuticals (Ratola $\boldsymbol{e t}$ al., 2012). Removal of TOrCs from wastewater has become a great concern because of their significant impacts on public health (Coday et al., 2014).

The removal of 26 trace organic compounds (TOrCs) using single-chamber aircathode MFC (SMFC) and double-chamber air-cathode MFC (DMFC) microbia fuel cells (MFC) was reported (Wang et al., 2015b). The results of the study showed that both sorption and biodegradation processes were involved for the removal of TOrCs. The removal efficiency was affected by the hydrophobicity and biodegradability probability of the compounds in case of neutral TOrCs Electrostatic interactions played an additional role in the MFCs. The removal of positively charged TOrCs was generally higher than negatively charged TOrCs. Negligible impact on MFC power generation was noted in presence of TOrCs.

\section{CONCLUSION}

This review mainly summarizes the recent reports on application of MFCs for the remediation of various pollutants. MFC technology can also be targeted towards future application in space technology on account of its power generation ability, sustainable energy generation and biosensor application. Although MFCs have been applied intensively over the past decades, limited success has been noted in practical application due to some limitations and challenges. Therefore, MFC technology has yet to find recognition and commercial success in environmental applications.

Acknowledgment: The authors are grateful to VIT University for the support throughout the study.

Conflict of Interest: The authors declare that there is no conflict of interest.

\section{REFERENCES}

Adelaja, O., Keshavarz, T., \& Kyazze, G. (2014). Enhanced biodegradation of phenanthrene using different inoculum types in a microbial fuel cell. Eng Life Sci, 14(2), 218-228. http://dx.doi.org/10.1002/elsc.201300089

Adelaja, O., Keshavarz, T. \& Kyazze, G. (2017). Treatment of phenanthrene and benzene using microbial fuel cells operated continuously for possible in situ and ex situ applications. Int Biodeter Biodegr, 116, 91-103. https://doi.org/10.1016/j.ibiod.2016.10.021

Ahmed, M. B., Zhou, J. L., Ngo, H. H., \& Guo, W. (2015). Adsorptive removal of antibiotics from water and wastewater: progress and challenges. Sci Total Environ, 532, 112-126. https://doi.org/10.1016/j.scitotenv.2015.05.130

Asenjo, N. G., A'lvarez, P., Granda, M., Blanco, C., Santamarı'a, R., \& Mene'ndez, R. (2011). High performance activated carbon for benzene/toluene adsorption from industrial wastewater. J Hazard Mater, 192(3), 1525-1532. https://doi.org/10.1016/j.jhazmat.2011.06.072

Bafana, A., Devi, S. S. \& Chakrabarti, T. (2011). Azo dyes: past, present and the future. Environ Rev, 19, 350-370. , https://doi.org/10.1139/a11-018

Boghani, H., Kim, J. R., Dinsdale, R. M., Guwy, A. J., \& Premier, G. C. (2017) Reducing the burden of food processing washdown wastewaters using microbial fuel cells. Biochem Eng J, 117(A), 210-217. https://doi.org/10.1016/j.bej.2016.10.017

Calabrese, E. J., \& Kenyon, E. M. (1991). Air toxins and risk assessment. Chelsea, Michigan: Lewis Publishers, pp. 483-488.

Cao, X., Song, H. L., Yu, C. Y., \& Li, X. N. (2015). Simultaneous degradation of toxic refractory organic pesticide and bioelectricity generation using a soil microbial fuel cell. Bioresource Technol, 189, 87-93. https://doi.org/10.1016/j.biortech.2015.03.148

Cao, X., Wang, H., Li, X. Q., Fang, Z., \& Li, X. N. (2017). Enhanced degradation of azo dye by a stacked microbial fuel cell-biofilm electrode reactor

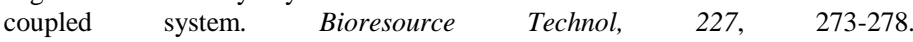
https://doi.org/10.1016/j.biortech.2016.12.043

Cercado-Quezada, B., Delia, M., \& Bergel, A. (2010). Testing various foodindustry wastes for electricity production in microbial fuel cell. Bioresource Technol, 101(8), 2748-2754. https://doi.org/10.1016/j.biortech.2009.11.076

Çetinkaya, A. Y., Köroğlu, E. O., Demir, N. M., Baysoy, D.Y., Özkaya, B., \& Cakmakçı, M. (2015). Electricity production by a microbial fuel cell fuelled by brewery wastewater and the factors in its membrane deterioration. Chinese $J$ Catalysis, 36(7), 1068-1076. https://doi.org/10.1016/S1872-2067(15)60833-6

Chae, K. J., Choi, M., Ajayi, F. F., Park, W., Chang, I. S., \& Kim, I. S. (2007) Mass transport through a proton exchange membrane (Nafion) in microbial fuel cells. Energ Fuel, 22(1), 169-176. https://doi.org/10.1021/ef700308u

Cheng, C.Y., Li, C. C., \& Chung, Y. C. (2014). Continuous electricity generation and pollutant removal from Swine wastewater using a single-chambered aircathode microbial fuel cell. Adv Mater Res, 953-954, 158-162. https://doi.org/10.4028/www.scientific.net/AMR.953-954.158 
Chen, X., Chen, M., Xu, B., Tang, R., Han, X., Qin, Y., Xu, B., Hang, B., Mao, Z., Huo, W., Xia, Y., Xu, Z., \& Wang, X. (2013). Parental phenols exposure and spontaneous abortion in Chinese population residing in the middle and lower reaches of the Yangtze River. Chemosphere, 93(2), 217-222. https://doi.org/10.1016/j.chemosphere.2013.04.067

Choi, C., \& Hu, N. (2013). The modeling of gold recovery from tetrachloroaurate wastewater using a microbial fuel cell. Bioresour Technol, 133, 589-598. https://doi.org/10.1016/j.biortech.2013.01.143

Coday, B. D., Yaffe, B. G. M., Xu, P., \& Cath, T. Y. (2014). Rejection of trace organic compounds by forward osmosis membranes: a literature review. Environ Sci Technol, 48(7), 3612-3624. https://doi.org/10.1021/es4038676

Coopman, V. A., Cordonnier, J. A., \& De Meyere, C. A. (2005). Fatal workplace accident involving ethyl acetate: a distribution study. Forensic Sci Int, 154(2-3), 92-95. https://doi.org/10.1016/j.forsciint.2004.09.112

Davì, M., \& Gnudi, F. (1999). Phenolic compounds in surface water. Water Res, 33(14), 3213-3219. https://doi.org/10.1016/S0043-1354(99)00027-5

de Dios, M. A. F., del Campo A. G., Fernández, F. J., Rodrigo, M., Pazos, M., \& Sanromán, M. Á. (2013) Bacterial-fungal interactions enhance power generation in microbial fuel cells and drive dye decolourisation by an ex situ and in situ electro-Fenton process. Bioresource Technol, 148, 39-46. https://doi.org/10.1016/j.biortech.2013.08.084

Devi, L. G., Kumar, S. G., Reddy, K. M., \& Munikrishnappa, C. (2009). Photo degradation of methyl orange an azo dye by advanced Fenton process using zero valent metallic iron: Influence of various reaction parameters and its degradation $\begin{array}{lllll}\text { mechanism. } J \text { Hazard } & \text { Mater, } & \text { 164(2-3), } & \text { 459-467. }\end{array}$ https://doi.org/10.1016/j.jhazmat.2008.08.017

Fang-Yuan, L., Huan, D., \& Feng, Z. (2013). Sulfur pollutants treatment using microbial fuel cells from perspectives of electrochemistry and microbiology. Chin J Anal Chem, 41(8), 1133-1139. https://doi.org/10.1016/S1872 2040(13)60669-6

Fang, Z., Song, H. L., Cang, N., \& Li, X. N. (2013). Performance of microbia fuel cell coupled constructed wetland system for decolorization of azo dye and bioelectricity generation. Bioresource Technol, 144, 165-171. https://doi.org/10.1016/j.biortech.2013.06.073

Fang, Z., Song, H., Yu, R., \& Li, X. (2016). A microbial fuel cell-coupled constructed wetland promotes degradation of azo dye decolorization products. Ecol Eng, 94, 455-463. https://doi.org/10.1016/j.ecoleng.2016.06.020

Field, J. A., \& Sierra-Alvarez, R. (2008). Microbial degradation of chlorinated phenols. Rev Environ Sci Biotechnol, 7(3), 211-241 https://doi.org/10.1007/s11157-007-9124-5

Gude, V. G. (2016). Wastewater treatment in microbial fuel cells - an overview. $J$ Cleaner Prod, 122, 287-307. https://doi.org/10.1016/j.jclepro.2016.02.022

Gurung, A., \& Oh, S. E. (2015). Rice straw as a potential biomass for generation of bioelectrical energy using microbial fuel cells (MFCs). Energ Source A, 37, 2625-2631. https://doi.org/10.1080/15567036.2012.728678

Guo, F., Fu, G., \& Zhang, Z. (2015). Performance of mixed-species biocathode microbial fuel cells using saline mustard tuber wastewater as self-buffered catholyte. Bioresource Technol, 180, 137-143. https://doi.org/10.1016/j.biortech.2014.11.113

Hassan, H., Jin, B., Dai, S., Ma, T., \& Saint, C. (2016a). Chemical impact of catholytes on Bacillus subtilis-catalysed microbial fuel cell performance for degrading 2,4-dichlorophenol. Chem Eng J, 301, 103-114. https://doi.org/10.1016/j.cej.2016.04.077

Hassan, H., Schulte-Illingheim, L., Jin, B., \& Dai, S. (2016b). Degradation of 2,4-Dichlorophenol by Bacillus subtilis with concurrent electricity generation in microbial fuel cell. Procedia Eng, 148, 370-377. https://doi.org/10.1016/j.proeng.2016.06.473

He, C. S., Mu, Z. X., Yang, H. Y., Wang, Y. Z., Mu, Y., \& Yu, H. Q. (2015). Electron acceptors for energy generation in microbial fuel cells fed with wastewaters: A mini-review. Chemosphere, 140, 12-17. https://doi.org/10.1016/j.chemosphere.2015.03.059

Hedbavna, P., Rolfe, S. A., Huang, W. E. \& Thornton, S. F. (2016). Biodegradation of phenolic compounds and their metabolites in contaminated groundwater using microbial fuel cells. Bioresource Technol, 200, 426-434. https://doi.org/10.1016/j.biortech.2015.09.092

Hong, J. M., Xia, Y. F., Hsueh, C. C., \& Chen, B. Y. (2016). Unveiling optima modes of operation for microbial fuel cell-aided dye bioremediation. J Taiwan Inst Chem Eng, 67, 362-369. https://doi.org/10.1016/j.jtice.2016.08.011

Hou, Y., Zhang, R., Yu, Z., Huang, L., Liu, Y., \& Zhou, Z. (2017). Accelerated azo dye degradation and concurrent hydrogen production in the single-chamber photocatalytic microbial electrolysis cell. Bioresource Technol, 224, 63-68 https://doi.org/10.1016/j.biortech.2016.10.069

Hsueh, C. C., Wang, Y. M., \& Chen, B. Y. (2014). Metabolite analysis on reductive biodegradation of Reactive Green 19 in Enterobacter cancerogenu. bearing microbial fuel cell (MFC) and non-MFC cultures. J Taiwan Inst Chem Eng, 45(2), 436-443. https://doi.org/10.1016/j.jtice.2013.05.003

Huang, L., Gan, L., Wang, N., Quan, X., Logan, B. E., \& Chen, G. (2012). Mineralization of pentachlorophenol with enhanced degradation and power generation from air cathode microbial fuel cells. Biotechnol Bioeng, 109(9), 2211-2221. http://dx.doi.org/10.1002/bit.24489
Huang, L., Sun, Y., Liu, Y., \& Wang, N. (2013b). Mineralization of 4 chlorophenol and analysis of bacterial community in microbial fuel cells Procedia Environ Sci, 18, 534-539. https://doi.org/10.1016/j.proenv.2013.04.072 Huang, L., Wang, Q., Quan, X., Liu, Y., \& Chen, G. (2013a) Bioanodes/biocathodes formed at optimal potentials enhance subsequent pentachlorophenol degradation and power generation from microbial fuel cells. Bioelectroch, 94, 13-22. https://doi.org/10.1016/j.bioelechem.2013.05.001

Huang, W., Chen, J., Hu, Y., Chen, J., Sun, J., \& Zhang, L. (2017). Enhanced simultaneous decolorization of azo dye and electricity generation in microbial fuel cell (MFC) with redox mediator modified anode. Int J Hydrogen Energ, 42(4), 2349-2359. https://doi.org/10.1016/j.ijhydene.2016.09.216

Hussain, A., Manuel, M., \& Tartakovsky, B. (2016). A comparison of simultaneous organic carbon and nitrogen removal in microbial fuel cells and microbial electrolysis cells. $J$ Environ Manage, 173, 23-33. https://doi.org/10.1016/j.jenvman.2016.02.025

Ieropoulos, I., Theodosiou, P., Taylor, B., Greenman, J., \& Melhuish, C. (2017) Gelatin as a promising printable feedstock for microbial fuel cells (MFC). Int $J$ $\begin{array}{lll}\text { Hydrogen } & \text { Energ, } & \text { 42(3), }\end{array}$ https://doi.org/10.1016/j.ijhydene.2016.11.083

Jadhav, G. S., Jagtap, Y. D., \& Ghangrekar, M. M. (2013). Dual chambered membrane microbial fuel cell: limitation on potential difference. Int J Eng Res Tech, 2(4), 1638-1643.

Jayashree, C., Arulazhagan, P., Kumar, S. A., Kaliappan, S., Yeom, I. T., \& Banu, J. R. (2014). Bioelectricity generation from coconut husk retting wastewater in fed batch operating microbial fuel cell by phenol degrading

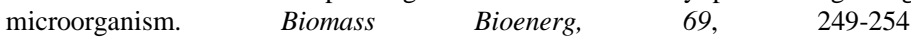
https://doi.org/10.1016/j.biombioe.2014.07.024

Kalleary, S., Abbas, F. M., Ganesan, A., Meenatchisundaram, S., Srinivasan, B. Packirisamy, A. S. B., Kesavan, R. K., \& Muthusamy, S. (2014). Biodegradation and bioelectricity generation by microbial desalination cell. Int Biodeter Biodegr 92, 20-25. https://doi.org/10.1016/j.ibiod.2014.04.002

Kassongo, J., \& Togo, C. A. (2011). Evaluation of full-strength paper mill effluent for electricity generation in mediator-less microbial fuel cells. Afr $J$ Biotechnol, 10(69), 15564-15570. https://doi.org/10.5897/AJB11.146

Katuri, K. P., Enright, A. M., O'Flaherty, V., \& Leech, D. (2012). Microbial analysis of anodic biofilm in a microbial fuel cell using slaughterhouse wastewater. Bioelectroch

https://doi.org/10.1016/j.bioelechem.2011.12.002

Khan, M. Z., Nizami, A. S., Rehan, M., Ouda, O. K. M., Sultana, S., Ismail, I. M., \& Shahzad, K. (2017). Microbial electrolysis cells for hydrogen production and urban wastewater treatment: A case study of Saudi Arabia. Appl Energ, 185(Part 1), 410-420. https://doi.org/10.1016/j.apenergy.2016.11.005

Kleinbeck, S., Juran, S. A., Kiesswetter, E., Schaper, M., Blaszkewicz, M., Bruning, T., \& van Thriel, C. (2008). Evaluation of ethyl acetate on three dimensions: investigation of behavioral, physiological and psychologica indicators of adverse chemosensory effects. Toxicol Lett, 182(1-3),102-109. https://doi.org/10.1016/j.toxlet.2008.09.001

Köroglu, E. O., Özkaya, B., Denktas, C., \& Çakmakci, M. (2014). Electricity generating capacity and performance deterioration of a microbial fuel cell fed with beer brewery wastewater. $J$ Biosci Bioeng, 118(6), 672-678. https://doi.org/10.1016/j.jbiosc.2014.05.006

Kuosa, M.,\& Kallas, J. (2009). Influence of t-butanol on multicomponent reaction kinetics and mass transfer in p-nitrophenol ozonation at low $\mathrm{pH}$. Chem Eng Process, 48(7), 1212-1221. https://doi.org/10.1016/j.cep.2009.04.008 Lens, P.\& Pol, L. W. H. (2000). Environmental technologies to treat sulfur pollution: principles and engineering. London:Intl Water Assn. Publishing. ISBN 1900222094

Lian, J., Tian, X., Guo, J., Guo, Y., Song, Y., Yue, L., Wang, Y., \& Liang, X (2016). Effects of resazurin on perchlorate reduction and bioelectricity generation in microbial fuel cells and its catalysing mechanism. Biochem Eng J, 114, 164 172. https://doi.org/10.1016/j.bej.2016.06.028

Lian, J., Tian, X., Li, Z., Guo, J., Guo, Y., Yue, L., Ping, J., \& Duan, L. (2017) The effects of different electron donors and electron acceptors on perchlorate reduction and bioelectricity generation in a microbial fuel cell. Int J Hydrogen Energ, 42(1), 544-552. https://doi.org/10.1016/j.ijhydene.2016.11.027

Li, J., Li, M., Zhang, J., Ye, D., Zhu, X., \& Liao, Q. (2013c). A microbial fuel cell capable of converting gaseous toluene to electricity. Biochem Eng J, 75, 3946. https://doi.org/10.1016/j.bej.2013.03.015

Liu, H., Hu, T. J., Zeng, G. M., Yuan, X. Z., Wu, J. J., Shen, Y., \&Yin, L. (2013) Electricity generation using p-nitrophenol as substrate in microbial fuel cell. Int Biodeter Biodegr, 76, 108-111. https://doi.org/10.1016/j.ibiod.2012.06.015 Liu, R., Gao, C., Zhao, Y., Wang, A., Lu, S., Wang, M., Maqboola, F., \& Huang, Q. (2012). Biological treatment of steroidal drug industrial effluent and electricity generation in the microbial fuel cells. Bioresource Technol, 123, 86-91. https://doi.org/10.1016/i.biortech.2012.07.094

Li, X., Jin, X., Zhao, N., Angelidaki, I., \& Zhang, Y. (2017). Novel bio-electroFenton technology for azo dye wastewater treatment using microbial reverseelectrodialysis electrolysis cell. Bioresource Technol, 228, 322-329. https://doi.org/10.1016/j.biortech.2016.12.114 
Li, X. M., Cheng, K. Y., Selvam, A., \& Wong, J. W. C. (2013a). Bioelectricity production from acidic food waste leachate using microbial fuel cells: effect of microbial inocula. Process Biochem, 48(2), 283-288. https://doi.org/10.1016/j.procbio.2012.10.001

Li, X., Zhu, N., Wang, Y., Li, P., Wu, P., \& Wu, J. (2013b). Animal carcass wastewater treatment and bioelectricity generation in up-flow tubular microbial fuel cells: effects of HRT and non-precious metallic catalyst. Bioresource Technol, 128, 454-460. https://doi.org/10.1016/j.biortech.2012.10.053

Mansoorian, H. J., Mahvi, A. H., Jafari, A. J., \& Khanjani, J. (2016). Evaluation of dairy industry wastewater treatment and simultaneous bioelectricity generation in a catalyst-less and mediator-less membrane microbial fuel cell. J Saudi Chem Soc, 20(1), 88-100. https://doi.org/10.1016/j.jscs.2014.08.002

Martelli, A., Mattioli, F., Pastorino, G., Robbiano, L., Allavena, A., \& Brambilla, G. (1991). Genotoxicity testing of chloramphenicol in rodent and human cells. Mutat Res, 260(1), 65-72. https://doi.org/10.1016/0165-1218(91)90081-V

Mohseni, M., \& Allen, D. G. (2000). Biofiltration of mixtures of hydrophilic and hydrophobic volatile organic compounds. Chem Eng Sci, 55(9), 1545-1558. https://doi.org/10.1016/S0009-2509(99)00420-0

Moon, H., Chang, I. S., \& Kim, B. H. (2006). Continuous electricity production from artificial wastewater using a mediator-less microbial fuel cell. Bioresource Technol, 97(4), 621-627. https://doi.org/10.1016/j.biortech.2005.03.027

Morata, T. C., Nyle'n, P., Johnson, A. C., \& Dunn, D. E. (1995). Auditory and vestibular functions after single or combined exposure to toluene: a review. Arch Toxicol, 69(7), 431-443.

Morris, J. M., \& Jin, S. (2012). Enhanced biodegradation of hydrocarboncontaminated sediments using microbial fuel cells. J Hazard Mat, 213-214, 474 477. https://doi.org/10.1016/j.jhazmat.2012.02.029

Mousavi, S., Ibrahim, S., Aroua, M. K., \& Ghafari, S. (2012). Development of nitrate elimination by autohydrogenotrophic bacteria in bio-electrochemica reactors - A review. Biochem Eng J, 67, 251-264. https://doi.org/10.1016/j.bej.2012.04.016

Nordin, N., Ho, L. N., Ong, S. A., Ibrahim, A. H., Wong, Y. S., Lee, S. L., Oon, Y. S., \& Oon, Y. L. (2017). Hybrid system of photocatalytic fuel cell and Fenton process for electricity generation and degradation of Reactive Black 5. Sep Purif Technol, 177, 135-141. https://doi.org/10.1016/j.seppur.2016.12.030

Nor, M. H. M., Mubarak, M. F. M, Elmi, H. S. A., Ibrahim, N., Wahab, M. F. A., \& Ibrahim, Z. (2015). Bioelectricity generation in microbial fuel cell using natural microflora and isolated pure culture bacteria from anaerobic palm oil mil effluent sludge. Bioresource Technol, 190, 458-465 https://doi.org/10.1016/j.biortech.2015.02.103

Oon, Y. S., Ong, S. A., Ho, L. N., Wong, Y. S., Oon, Y. L., Lehl, H. K., Thung, W. E., \& Nordin, N. (2017). Microbial fuel cell operation using monoazo and diazo dyes as terminal electron acceptor for simultaneous decolourisation and bioelectricity generation. $J$ Hazard Mater, 325, 170-177. https://doi.org/10.1016/j.jhazmat.2016.11.074

Park, H. I., Kim, D. K., Choi, Y. J., \& Pak, D. (2005). Nitrate reduction using an electrode as direct electron donor in a biofilm electrode reactor. Process Biochem, 40(10), 3383-3388. https://doi.org/10.1016/j.procbio.2005.03.017

Patil, S. A., Surakasi, V. P., Koul, S., Ijmulwar, S., Vivek, A., Shouche, Y. S., \& Kapadnis, B. P. (2009). Electricity generation using chocolate industry wastewater and its treatment in activated sludge based microbial fuel cell and analysis of developed microbial community in the anode chamber. Bioresource Technol, 100(21), 5132-5139. https://doi.org/10.1016/j.biortech.2009.05.041 Penteado, E. D., Fernandez-Marchante, C. M., Zaiat, M., Cañizares, P. Gonzalez, E. R., \& Rodrigo, M. A. R. (2015). Energy recovery from winery wastewater using a dual chamber microbial fuel cell. J Chem Technol Biotechnol, 91(6), 1802-1808. http://dx.doi.org/10.1002/jctb.4771

Popa, C., Favier, L., Dinica, R., Semrany, S., Djelal, H., Amrane, A., \& Bahrim, G. (2014). Potential of newly isolated wild Streptomyces strains as agents for the biodegradation of a recalcitrant pharmaceutical, carbamazepine. Environ Technol, 35(21-24), 3082-3091. https://doi.org/10.1080/09593330.2014.931468 Rahimnejad, M., Adhami, A., Darvari, S., Zirepour, A., \& Oh, S. E. (2015) Microbial fuel cell as new technology for bioelectricity generation: a review. Alexandria Eng J, 54(3), 745-756. https://doi.org/10.1016/j.aej.2015.03.031

Ratola, N., Cincinelli, A., Alves, A., \& Katsoyiannis, A. (2012). Occurrence of organic microcontaminants in the wastewater treatment process: A mini review. $J$ Hazard Mater, 239-240, 1-18. https://doi.org/10.1016/j.jhazmat.2012.05.040

Saeed, H. M., Husseini, G. A., Yousef, S., Saif, J., Al-Asheh, S., Fara, A. A. Azzam, S., Khawaga, R., \& Aidan, A. (2015). Microbial desalination cell technology: A review and a case study. Desalination, 359, 1-13. https://doi.org/10.1016/j.desal.2014.12.024

Sangeetha, T., \& Muthukumar, M. (2013). Influence of electrode material and electrode distance on bioelectricity production from sago-processing wastewater using microbial fuel cell. Environ Prog Sustain Energy, 32(2), 390-395. http://dx.doi.org/10.1002/ep.11603

Sherafatmand, M., \& Ng, H. Y. (2015). Using sediment microbial fuel cells (SMFCs) for bioremediation of polycyclic aromatic hydrocarbons (PAHs) Bioresource Technol. 195

122-130.
Sun, J., Cai, B., Zhang, Y., Peng, Y., Chang, K., Ning, X., Liu, G., Yao, K. Wang, Y., Yang, Z., \& Liu, J. (2016). Regulation of biocathode microbial fuel cell performance with respect to azo dye degradation and electricity generation via the selection of anodic inoculum. Int J Hydrogen Energ, 41(9), 5141-5150. https://doi.org/10.1016/i.ijhydene.2016.01.114

Sun, J., Hu, Y., \& Hou, B. (2011). Electrochemical characterization of the bioanode during simultaneous azo dye decolorization and bioelectricity generation in an air-cathode single chambered microbial fuel cell. Electrochim Acta, 56(19), 6874-6879. http://dx.doi.org/10.1016/j.electacta.2011.05.111

Sun, J., Li, W., Li, Y., Hu, Y., \& Zhang, Y. (2013). Redox mediator enhanced simultaneous decolorization of azo dye and bioelectricity generation in air cathode microbial fuel cell. Bioresource Technol, 142, 407-414. https://doi.org/10.1016/j.biortech.2013.05.039

Sun, Q., Li, Y., Chou, P. H., Peng, P. Y., \& Yu, C. P. (2012). Transformation of bisphenol A and alkylphenols by ammonia-oxidizing bacteria through nitration. Environ Sci Technol, 46(8), 4442-4448. https://doi.org/10.1021/es204424t

Tharali, A. D., Sain, N., \& Osborne, W. J. (2016). Microbial fuel cells in bioelectricity production. Frontiers Life Sci, 9(4), 252-266. https://doi.org/10.1080/21553769.2016.1230787

Thomas, Y. R. J., Picot, M., Carer, A., Berder, O., Sentieys, O., \& Barrière, F. (2013). A single sediment-microbial fuel cell powering a wireless telecommunication system. $J$ Power Sources, 241, 703-708. https://doi.org/10.1016/j.jpowsour.2013.05.016

Thung, W. E., Ong, S. A., Ho, L. N., Wong, Y. S., Ridwan, F., Oon, Y. L., Oon, Y. S., \& Lehl, H. K. (2015). A highly efficient single chambered up-flow membrane-less microbial fuel cell for treatment of azo dye Acid Orange 7 containing wastewater. Bioresource Technol, 197, 284-288. https://doi.org/10.1016/j.biortech.2015.08.078

Wang, H., Heil, D., Ren, Z. J., \& Xu, P. (2015b). Removal and fate of trace organic compounds in microbial fuel cells. Chemosphere, 125, 94-101. https://doi.org/10.1016/j.chemosphere.2014.11.048

Wang, L., Liu, Y., Ma, J., \& Zhao, F. (2016). Rapid degradation of sulphamethoxazole and the further transformation of 3-amino-5-methylisoxazole in a microbial fuel cell. Water Res, 88, 322-328. https://doi.org/10.1016/j.watres.2015.10.030

Wang, Y., Feng, C., Li, Y., Gao, J., \& Yu, C. P. (2017). Enhancement of emerging contaminants removal using Fenton reaction driven by $\mathrm{H}_{2} \mathrm{O}_{2}$-producing microbial fuel cells. Chem Eng J, 307, 679-686. https://doi.org/10.1016/j.cej.2016.08.094

Wang, Z. C., Gao, M. C., Zhang, Y., She, Z. L., Ren, Y., Wang, Z., \& Zhao, C. C. (2014). Perchlorate reduction by hydrogen autotrophic bacteria in a bioelectrochemical reactor. $J$ Environ Manage, 142, 10-16 https://doi.org/10.1016/j.jenvman.2014.04.003

Wang, Z., Zhang, B., Borthwick, A. G. L., Feng, C., \& Ni, J. (2015a). Utilization of single-chamber microbial fuel cells as renewable power sources for electrochemical degradation of nitrogen-containing organic compounds. Chem Eng J, 280, 99-105. https://doi.org/10.1016/j.cej.2015.06.012

Wu, C. H., I, Y. P., Chiu, Y. H., \& Lin, C. W. (2014). Enhancement of power generation by toluene biodegradation in a microbial fuel cell in the presence of pyocyanin. $J$ Taiwan Inst Chem Eng, 45, 2319-2324. https://doi.org/10.1016/j.jtice.2014.05.019

Wu, C. H., \& Lin, C. W. (2016). Electricity generation and kinetic aspects of a biotrickling filter-microbial fuel cell for the biofiltration of ethyl acetate vapor from waste gas. J Taiwan Inst Chem Eng, 68, 332-337. https://doi.org/10.1016/j.jtice.2016.09.023

Wu, C. H., Shih, J. C., \& Lin, C. W. (2016a). Continuous production of power using microbial fuel cells with integrated biotrickling filter for ethyl acetatecontaminated air stream treatment. Int J Hydrogen Energ, 41(47), 21945-21954. https://doi.org/10.1016/j.ijhydene.2016.08.186

Wu, C. H., Tsai, Y. Y., \& Lin, C. W. (2016b). Modifying membrane anode in a microbial fuel cell to improve removal of gaseous ethyl acetate without reducing generation of electricity. $J$ Taiwan Inst Chem Eng, 62, 169-176. https://doi.org/10.1016/j.jtice.2016.02.001

Xu, Q., Sun, J., Hua, Y. Y., Chen, J., \& Li, W. J. (2013). Characterization and interactions of anodic isolates in microbial fuel cells explored for simultaneous electricity generation and Congo red decolorization. Bioresource Technol, 142, 101-108. https://doi.org/10.1016/j.biortech.2013.05.025

Xu, X., Gao, B. Y., Jin, B., Zhen, H., Wang, X. Y., \& Dai, M. (2015). Study of microbial perchlorate reduction: considering of multiple $\mathrm{pH}$ : electron acceptor and donors. $J$ Hazard Mater, 285, 228-235. https://doi.org/10.1016/j.jhazmat.2014.10.061

Yang, J., Zhou, M., Zhao, Y., Zhang, C., \& Hu, Y. (2013). Electrosorption driven by microbial fuel cells to remove phenol without external power supply. Bioresource Technol, https://doi.org/10.1016/j.biortech.2013.09.107

Yang, L. M., Yu, L. E., \& Ray, M. B. (2009). Photocatalytic oxidation of paracetamol: dominant reactants, intermediates, and reaction mechanisms. Environ Sci Technol, 43(2), 460-465. https://doi.org/10.1021/es8020099

Yu, C. P., \& Chu, K. H. (2009). Occurrence of pharmaceuticals and personal care products along the West Prong Little Pigeon River in east Tennessee, USA. 
Zhang, B., Liu, Y., Tong, S., Zheng, M., Zhao, Y., Tian, C., Liu, H., \& Feng, C. (2014). Enhancement of bacterial denitrification for nitrate removal in groundwater with electrical stimulation from microbial fuel cells. J Power Source, 268, 423-429. https://doi.org/10.1016/j.jpowsour.2014.06.076

Zhang, B., Wang, Z., Zhou, X., Shi, C., Guo, H., \& Feng, C. (2015b). Electrochemical decolorization of methyl orange powered by bioelectricity from single-chamber microbial fuel cells. Bioresource Technol, 181, 360-362. https://doi.org/10.1016/j.biortech.2015.01.076

Zhang, D., Li, Z., Zhang, C., Zhou, X., Xiao, Z., Awata, T., \& Katayama, A (2017b). Phenol-degrading anode biofilm with high coulombic efficiency in graphite electrodes microbial fuel cell. J Biosci Bioeng, 123(3), 364-369. https://doi.org/10.1016/j.jbiosc.2016.10.010

Zhang, J. S., Sun, Z. T., Li, Y., Peng, X., Li, W., \& Yan, Y. (2009). Biodegradation of p-nitrophenol by Rhodococcus sp. CN6 with high cell surface $\begin{array}{lllll}\text { hydrophobicity. } J & \mathrm{H} & \text { Hazard } & \text { Mater, } & 163,728 .\end{array}$ https://doi.org/10.1016/j.jhazmat.2008.07.018

Zhang, L., Yin, X., \& Li, S. F. Y. (2015a). Bio-electrochemical degradation of paracetamol in a microbial fuel cell-Fenton system. Chem Eng J, 276,185-192. https://doi.org/10.1016/j.cej.2015.04.065

Zhang, Q., Zhang, Y., \& Li, D. (2017a). Cometabolic degradation of chloramphenicol via a meta-cleavage pathway in a microbial fuel cell and its microbial community. Bioresource Technol, 229, 104-110. https://doi.org/10.1016/j.biortech.2017.01.026 